\title{
Suckling and by Pass Fat in the Postpartum Reproductive Activity of Hair Sheep
}

\author{
Osorio-Marín, Yolanda $^{1}$; Torres-Hernández, Glafiro ${ }^{1}$; Becerril-Pérez, Carlos Miguel ${ }^{2}$, \\ Gallegos-Sánchez, Jaime ${ }^{1 *}$
}

${ }^{1}$ Colegio de Postgraduados Campus Montecillo. Carretera Federal México-Texcoco km 36.5, Montecillo, Texcoco, Estado de México, México. C.P. 56230.

2 Colegio de Postgraduados Campus Veracruz. Carretera Federal Xalapa-Veracruz km 88.5, vía Paso de Ovejas entre Paso San Juan y Puente Jula, Tepetates, Manlio F. Altamirano, Veracruz, México. G.P. 91690.

* Corresponding Author: gallegos@colpos.mx

Gitation: Osorio-Marín, Y., TorresHernández, G., Becerril-Pérez, C. M. Gallegos-Sánchez, J. (2021) Suckling and by Pass Fat in the Postpartum Reproductive Activity of Hair Sheep. Agro Productividad. https://doi. org/10.32854/agrop.v14i8.2107

Editor in Chief: Dr. Jorge Cadena Iñiguez

Received: January, 2021.

Accepted: August, 2021

Agro Productividad, 14(8). August. 2021 pp: 127-134.

This work is licensed under a Creative Commons Attribution-NonCommercial 4.0 International license.

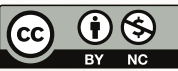

\begin{abstract}
Objective: To evaluate the effect of by pass fat and suckling control on postpartum reproductive activity of hair ewes.

Design/Methodology/Approach: Eighty-one (81) hair ewes with average weight of $58 \pm 8 \mathrm{~kg}$ were used, which on postpartum day 7 were assigned to one of four treatments under a completely randomized design with $2 \times 2$ factorial arrangement. Factor A is the type of suckling [continuous suckling (CS) and suckling control $(\mathrm{SC})]$ and factor B, by pass fat (with or without). In CS, ewes remained with their offspring 24 hours a day $(n=16)$. In continuous suckling plus fat (CSF), ewes remained with the offspring all day plus the addition of $8 \%$ in dietary fat $(\mathrm{n}=24)$. In $\mathrm{SC}$, it was 30 min of suckling only twice per day $(\mathrm{n}=14)$. In suckling control plus fat (SCF), controlled suckling lasted $30 \mathrm{~min}$, twice a day plus $8 \%$ fat $(\mathrm{n}=25)$.

Results: The response to the treatments was similar $(\mathrm{p}>0.05)$ in onset of estrus, return rate, gestation, prolificacy and fertilization; for the lambing rate variable, there were differences ( $\mathrm{p} \leq 0.05)$, the SCF treatment was higher $(68 \%)$ compared to CS $(50 \%)$ and CSF $(50 \%)$, but equal $(\mathrm{p}<0.05)$ to SC $(57.1 \%)$.

Implications: In this experiment, it was observed that the SCF treatment presented a better response, implying that controlling suckling and providing by pass fat helps to restore ovarian activity sooner after lambing.

Conclusions: Suckling control plus inclusion of dietary by pass fat in ovulation induction protocols during early postpartum (around day 25 postpartum) can be included in routine reproductive management of flocks, improving the reproductive efficiency of hair sheep.
\end{abstract}

Keywords: anestrus, excess fat, lactation, supplementation, lambing rate.

\section{INTRODUCTION}

Sheep farming is an activity of great economic importance in Mexico, and this can be sustained with the growing demand for meat of this species. In addition, imports evidence the need to produce increasingly more (SIAP, 2019). 
This can be achieved if emphasis is placed, among others, on improving the reproductive parameters of the flocks; that is, if the number of lambs born per ewe at each lambing is increased through various reproductive techniques and adequate knowledge in physiology and endocrinology, since they are essential to improve the reproductive efficiency of the flock (Meikle et al., 2001; Cortez-Romero and Gallegos-Sánchez, 2014).

Adequate nutrient supply at appropriate times during gestation ensures successful productive and reproductive efficiency of mothers and offspring during postpartum (Radunz et al., 2011; Abdalla et al., 2012; Mahboub et al., 2013; Vicente-Pérez et al., 2015). Therefore, high energy diets have been used to cover the ewes' energy requirements. Among the ingredients that have been used, the use of excess fat to cover such energy requirements stands out (Machmüller et al., 2000; Bhatt et al., 2013; Bianchi et al., 2018). It has been observed that by pass fat escapes fermentation and bio-hydrogenation that takes place in the rumen, in addition to improving fiber digestibility (Palmquist and Jenkins, 1980; Behan et al., 2019).

Also, it has been shown that suckling control during lactation can decrease or inhibit the negative effects that the negative energy balance and continued suckling often have on follicular development and ovulation after lambing (Fray et al., 1995; Scaramuzzi et al., 1996; Abu Ishmais et al., 2004; Morales-Terán et al., 2004; Pérez-Hernández et al., 2009; Castillo-Maldonado et al., 2013). Therefore, the objective of the present study was to evaluate the effect of suckling control and by pass fat on the restoration of postpartum ovarian activity in hair ewes.

\section{MATERIALS AND METHODS}

Location of the study area. The study was conducted at the Sheep and Goat Reproduction Laboratory (LaROCa) of Colegio de Postgraduados, located in Montecillo, Texcoco de Mora, Estado de México (19²9' LN and 98 53' LW) at an altitude of 2250 $\mathrm{m}$. The region has a temperate climate $[\mathrm{C}(\mathrm{W})]$, mean annual rainfall of $664 \mathrm{~mm}$ and average annual temperature of $15^{\circ} \mathrm{C}$ (García, 2004).

Animals, management and treatments. A total of 81 multiparous hair ewes were used, with lambing at the end of November, and average weight of $58 \pm 8 \mathrm{~kg}$ at lambing. Seven days after lambing, ewes were assigned to one of four treatments using a completely randomized design with factorial arrangement, where factor A is type of suckling [continuous suckling (CS) and suckling control (SC)] and factor B is fat use (fat and nonfat). In continuous suckling (CS; $\mathrm{n}=16)$, mother and lamb remained together for $24 \mathrm{~h}$ per day. In continuous suckling + fat (CSF; $n=26)$, the mother remained in contact with the lamb $24 \mathrm{~h}$ per day, and $8 \%$ fat was added to the diet. In suckling control (SC; $\mathrm{n}=14$ ), suckling was controlled for $1 \mathrm{~h}$ per day, that is, $30 \mathrm{~min}$ of suckling twice a day, and the rest of the time the lambs were separated from their mothers. In suckling control + fat (SCF; $\mathrm{n}=25$ ), suckling was controlled for $30 \mathrm{~min}, 2$ times per day, and $8 \%$ by pass fat was added to the diet; the remaining time, mothers and lambs were separated. The lambs were weaned at 60 days of age.

Feeding. The ewes were fed a balanced diet covering the nutritional needs of ewes in the physiological stage of lactation $\left(2.3 \mathrm{Mcal} \mathrm{kg}^{-1}\right.$ dry matter of metabolizable energy and 
$15 \%$ crude protein), according to the recommendations (NRC, 2007). For the treatments where by pass fat was offered, $8 \%$ of this ingredient was added in the diet (Table 1). Water availability was ad libitum during the entire study.

The experimental diets were offered from day 5 , when the ovulation induction protocol was started, until day 9. As for the lambs, they were fed on the colostrum produced by their mothers during the first days of life. On day 7 of birth, they were assigned with their mothers to the respective treatments. Lambs assigned to suckling control were separated from their mothers and provided with free access to pelleted starter concentrate (creepfeeding) in their pens.

Ovulation induction. The ovulation induction protocol consisted of the insertion of an intravaginal device (CIDR, Controlled Internal Drug Release; with $0.3 \mathrm{~g}$ of progesterone, Pfizer) in the ewe for 9 days starting on postpartum day 25. At 48 hours before withdrawal, $1 \mathrm{~mL}$ of prostaglandin (PGF2 $\alpha$, Dinoprost; Lutalyse, Pharmacia \& Upjhon, Michigan, USA) ewe ${ }^{-1}$ was applied intramuscularly. The CIDR was removed and detecting estrus was immediately done every $4 \mathrm{hr}$ for $72 \mathrm{hr}$ with the help of male sires equipped with special aprons to prevent copulation.

Artificial insemination. Prior to insemination, semen was collected and evaluated from healthy and reproductively suitable rams. Artificial insemination (AI) was performed between 12 and 18 hours after estrus. The ewes were shaved and disinfected in the abdominal region. Insemination was then performed by the abdominal laparoscopy technique, in which a $0.25 \mathrm{~mL}$ with semen was introduced and a half dose was deposited in each uterine horn.

Diagnosis of pregnancy. Pregnancy diagnosis was performed by ultrasonography at 35 days post-insemination with the aid of a trans-rectal transducer integrated to an ultrasound equipment (Aloka SSD 500).

Reproductive variables. The following reproductive variables were evaluated to assess the restart of postpartum reproductive activity in ewes.

Estrus response. Number of ewes that showed signs of estrus after removal of the device, with respect to the total number of ewes in each treatment.

Table 1. Ingredients of the experimental diets offered to hair ewes.

\begin{tabular}{l|c|c|c|c}
\hline \multirow{2}{*}{\multicolumn{1}{c}{ Ingredient (\%)* }} & \multicolumn{4}{c}{ Treatments } \\
\cline { 2 - 5 } & $\mathbf{A C}$ & $\mathbf{A c}+\mathbf{G}$ & $\mathbf{C A}$ & $\mathbf{C A}+\mathbf{G}$ \\
\hline Wheat straw & 40 & 36 & 40 & 36 \\
\hline Alfalfa & 29 & 25 & 29 & 25 \\
\hline Concentrate & 20 & 20 & 20 & 20 \\
\hline Corn & 5 & 5 & 5 & 5 \\
\hline By pass fat & 0 & 8 & 0 & 8 \\
\hline Minerals & 1 & 1 & 1 & 1 \\
\hline Molasses & 5 & 5 & 5 & 5 \\
\hline
\end{tabular}

*Portions calculated on the basis of what was offered per kg of dry matter. AC: Continuous suckling, ACG: By pass fat + Continuous suckling, CA: Control suckling, CAG: By pass fat + control suckling. 


$$
\% \text { Estrus }=\frac{\text { Number of ewes that showed estrus }}{\text { Total number of ewes in each treatment }} \times 100
$$

Onset at estrus. Interval between removal of CIDR and onset of estrus. The distribution was determined by the number of ewes that went into estrus up to 72 hours after removal of the CIDR.

Return to estrus. Number of ewes that showed estrus 17 or 34 days post-insemination.

$$
\% \text { Return to estrus }=\frac{\text { Number of ewes that showed estrus } 17 \text { or } 34 \text { days post-insemination }}{\text { Total number of ewes in each treatment }} \times 100
$$

Pregnancy rate. Number of ewes diagnosed as pregnant with respect to the total number of ewes per treatment.

$$
\% \text { Pregnancy rate }=\frac{\text { Number of ewes diagnosed as pregnant }}{\text { Total number of ewes in each treatment }} \times 100
$$

Lambing rate. Number of ewes lambed in relation to the total number of ewes per treatment.

$$
\% \text { Lambing rate }=\frac{\text { Number of ewes lambed }}{\text { Total number of ewes in each treatment }} \times 100
$$

Fertility. Total number of lambs born in relation to the total number of ewes per treatment.

$$
\text { Fertility }=\frac{\text { Number of lambs born }}{\text { Total number of ewes in each treatment }}
$$

Prolificacy. Number of lambs born in relation to the number of ewes lambed per treatment.

$$
\text { Prolificacy }=\frac{\text { Number of lambs born }}{\text { Number of ewes lambed }}
$$

Statistical analysis. The statistical package Statistical Analysis Systems (SAS, 2012) was used for data analysis, considering significant differences at $p \leq 0.05$. The variables response to estrus, return to estrus, gestation rate and lambing rate were analyzed by logistic regression with PROG LOGISTIC. The variables prolificacy and fertility were analyzed by means of a POISSON distribution using PROC GENMOD. For the variable onset at estrus, the Shapiro and Wilk test (Shapiro and Wilk, 1965) was performed to 
observe univariate normality and then the analysis was performed with the Kaplan Meier survival curves method using the Log-Rank test, with the LIFESTEST procedure.

\section{RESULTS AND DISCUSSION}

The results obtained are shown in Table 2. No significant differences were found in the variables response to estrus, return to estrus, pregnancy rate, prolificacy, or fertility. Differences ( $\mathrm{p}>0.05)$ were only observed in lambing rate.

Figure 1 shows the survival curves of the treatments; it shows the distribution of the hours of onset at estrus for each treatment. The onset at estrus was not affected by the

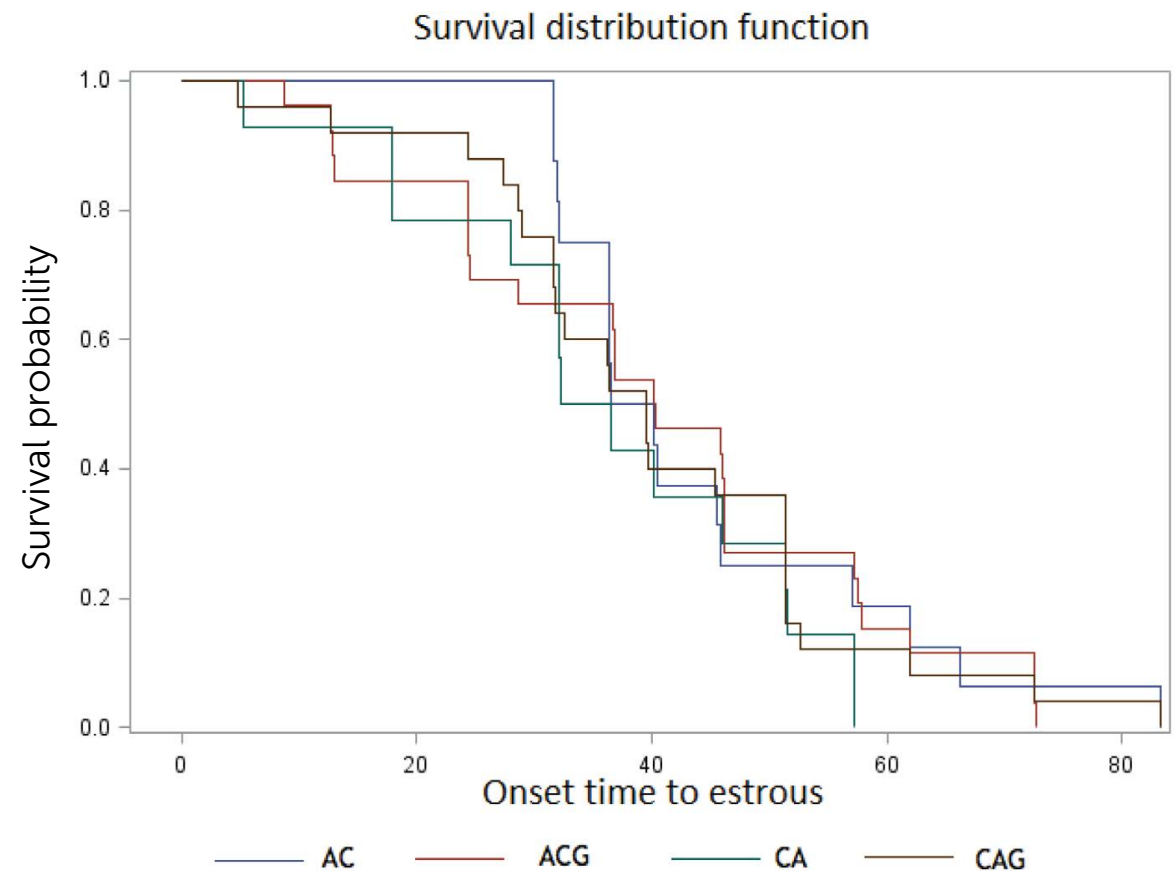

Figure 1. Survival curves from onset to estrus formed by Kaplan Meier survival estimators at different times per treatment $(\mathrm{P}<0.05)$.

AC: Continuous suckling, ACG: By pass fat + Continuous suckling, CA: Control suckling, CAG: By pass fat + control suckling.

Table 2. Reproductive variables evaluated in the postpartum of hair ewes.

\begin{tabular}{|c|c|c|c|c|c|c|c|}
\hline Treatment & $\mathbf{n}$ & $\begin{array}{c}\text { Rate of estrous } \\
(\%)\end{array}$ & $\begin{array}{c}\text { Rate of return } \\
(\%)\end{array}$ & $\begin{array}{c}\text { Rate of pregnancy } \\
(\%)\end{array}$ & $\begin{array}{c}\text { Rate of lambing } \\
(\%)\end{array}$ & Prolificacy & Fecundity \\
\hline $\mathrm{AC}$ & 16 & $\begin{array}{c}100^{\mathrm{a}} \\
(16 / 16)\end{array}$ & $\begin{array}{l}31.3^{\mathrm{a}} \\
(5 / 16)\end{array}$ & $\begin{array}{c}50^{\mathrm{a}} \\
(8 / 16)\end{array}$ & $\begin{array}{c}50^{\mathrm{a}} \\
(8 / 16)\end{array}$ & $1.5^{\mathrm{a}}$ & $\begin{array}{c}0.75^{\mathrm{a}} \\
(12 / 16)\end{array}$ \\
\hline $\mathrm{ACG}$ & 26 & $\begin{array}{c}100^{\mathrm{a}} \\
(26 / 26) \\
\end{array}$ & $\begin{array}{l}23.1^{\mathrm{a}} \\
(6 / 26) \\
\end{array}$ & $\begin{array}{c}50^{\mathrm{a}} \\
(13 / 26) \\
\end{array}$ & $\begin{array}{c}50^{\mathrm{a}} \\
(13 / 26)\end{array}$ & $1.7^{\mathrm{a}}$ & $\begin{array}{c}0.84^{\mathrm{a}} \\
(22 / 26)\end{array}$ \\
\hline CA & 14 & $\begin{array}{c}100^{\mathrm{a}} \\
(14 / 14) \\
\end{array}$ & $\begin{array}{l}42.9^{\mathrm{a}} \\
(6 / 14)\end{array}$ & $\begin{array}{l}57.1^{\mathrm{a}} \\
(8 / 14) \\
\end{array}$ & $\begin{array}{l}57.1^{\text {ab }} \\
(8 / 14)\end{array}$ & $1.8^{\mathrm{a}}$ & $\begin{array}{c}1.0^{\mathrm{a}} \\
(14 / 14) \\
\end{array}$ \\
\hline CAG & 25 & $\begin{array}{c}100^{\mathrm{a}} \\
(25 / 25)\end{array}$ & $\begin{array}{c}12^{\mathrm{a}} \\
(3 / 25)\end{array}$ & $\begin{array}{c}68^{\mathrm{a}} \\
(17 / 25)\end{array}$ & $\begin{array}{l}68.0^{\mathrm{b}} \\
(17 / 25)\end{array}$ & $1.9^{\mathrm{a}}$ & $\begin{array}{c}1.32^{\mathrm{a}} \\
(33 / 25)\end{array}$ \\
\hline
\end{tabular}

AC: Continuous suckling, ACG: By pass fat + Continuous suckling, CA: Control suckling, CAG: By pass fat + control suckling.

${ }^{\mathrm{a}, \mathrm{b}}$ Different letters between rows indicate differences $(\mathrm{P}<0.05)$. 
addition of by pass fat or suckling control, however, it is shown that ewes belonging to the SC group (suckling control) went into estrus on average at 36.09 \pm 4.19 hours, and the total ewes in that treatment before 60 hours after removal of the device. In the same way, it can be observed that ewes with continuous suckling were the last to come into estrus, after 80 hours.

Regarding the variable rate of return to estrus, it was found that the CS treatment had $31.3 \%$, CSF $23.1 \%$, SC $42.9 \%$ and SCF 12\%, with no significant differences ( $p>0.05$ ). Similarly, the pregnancy rate had no significant differences $(p>0.05)$. For the lambing rate variable, the results obtained show differences $(\mathrm{p} \leq 0.05)$ and it is observed that the SCF treatment was higher (68\%), compared to CS (50\%) and CSF (50\%), but equal ( $\mathrm{p}>0.05)$ to SC (57.1\%); while C.S and CSF were equal ( $\mathrm{p}>0.05)$.

It has been shown that hair ewes respond satisfactorily to the ovulation induction protocols before 60 days postpartum (Morales-Terán et al., 2011). This information is similar to that reported by Castillo-Maldonado et al. (2013) who showed that ewes restart their postpartum reproductive activity around day 35 after lambing. Likewise, in this study, ovulation induction in hair ewes was performed on average on postpartum day 25 , with the aim of performing artificial insemination on approximately postpartum day 35. In addition, it was observed that ewes responded to the ovulation induction protocol, as all ewes showed signs of estrus after CIDR withdrawal. It has also been shown that decreasing the contact of the lamb with its mother positively increases the response to ovulation induction protocols; that is, females with suckling control reestablish ovarian activity sooner than females with continuous suckling after lambing (Morales-Terán $e t$ al., 2011; Castillo-Maldonado et al., 2013).

The lambing rate results found in this experiment agree with authors who reported that continuous suckling causes a lower lambing rate, confirming that the effect of suckling is a factor that directly influences the inhibition of postpartum ovarian activity in ewes (Fraire-Cordero et al., 2018), as it is known to inhibit the secretion frequency of $\mathrm{GnRH} / \mathrm{LH}$ pulses. A possible reason to explain the better response of the SCF treatment may be because of the interaction observed between suckling control and by pass fat, that is, a decrease in suckling frequency (reducing the number of times the lamb sucks the mammary gland) and an increase in available energy that helps to increase the frequency of secretion of gonadotropin ( $\mathrm{LH}$ and FSH) pulses, although some authors, such as Bayourthe et al. (1993) mentioned that an increase of more than 5\% of excess fat in the diet causes negative effects on fiber digestibility, and also a decrease in the population of ruminal microorganisms (Palmquist and Jenkins, 1980). However, in this study, where $8 \%$ of fat was used in the diet, no decrease in the reproductive variables studied was observed.

\section{GONGLUSIONS}

Suckling control plus the inclusion of dietary by pass fat in ovulation induction protocols during early postpartum (around day 25 postpartum) can be included in routine reproductive management of flocks, thus improving the reproductive efficiency of hair ewes. 


\section{REFERENGES}

Abdalla, E.B., Abou-Ammou, F.F., El-Shafie, M.H., El-Bordeny, N.E., Hamida, R.M. (2012). Effect of feeding levels on the reproductive performance of Barki sheep. Egyptian Journal of Sheep E Goat Sciences, 7(2), 11-15.

Abu Ishmais, M.A., Kridli, R.T., Omer, S.A. (2004). Body Weight Change, Milk Production and Reproductive Parameters in Suckled vs. Non-suckled Awassi Ewes. Asian-Australasian Journal of Animal Sciences, 17(9), 1236-1240. Doi: 10.5713/ajas.2004.1236

Bayourthe, C., Moncoulon, R., Vernay, M. (1993). Effect of protein-protected fat on ruminal and total nutrient digestibility of sheep diets. Journal of Animal Science, 71(4), 1026-1031. Doi: 10.2527/1993.7141026x

Behan, A.A., Loh, T.G., Fakurazi, S., Kaka, U., Kaka, A., Samsudin, A.A. (2019). Effects of Supplementation of Rumen Protected Fats on Rumen Ecology and Digestibility of Nutrients in Sheep. Animals, 9(7), 400. Doi: 10.3390/ani9070400

Bhatt, R.S., Sahoo, A., Shinde, A.K., Karim, S.A. (2013). Change in body condition and carcass characteristics of cull ewes fed diets supplemented with rumen bypass fat. Livestock Science, 157(1), 132-140. Doi: 10.1016/j.livsci.2013.06.025

Bianchi, A.E., Macedo, V.P., Silva, A.S.D., Silveira, A.L.F. da, Hill, J.A.G., Zortéa, T., Rossi, R.M., Batista, R. (2018). Effect of the addition of protected fat from palm oil to the diet of dairy sheep. Revista Brasileira de Zootecnia, 47. Doi: 10.1590/rbz4720160137

Castillo-Maldonado, P.P., Vaquera-Huerta, H., Tarango-Arambula, L.A., Pérez-Hernández, P., HerreraCorredor, A.C., Gallegos-Sánchez, J. (2013). Restablecimiento de la actividad reproductiva posparto en ovejas de pelo. Archivos de Zootecnia, 62(239), 419-428. Diu: 10.4321/S0004-05922013000300010

Cortez-Romero, C., Gallegos-Sánchez, J. (2014). Biotecnologías reproductivas, moleculares y génicas en ovinos. Biblioteca Básica de Agricultura, Colegio de Postgraduados. pp 277

Fraire-Cordero, S., Salazar-Ortiz, J., Cortez-Romero, C., Pérez-Hernández, P., Herrera-Corredor, C.A., Gallegos-Sánchez, J. (2018). External stimuli help restore post-partum ovarian activity in Pelibuey sheep. South African Journal of Animal Science, 48(2), 337. Doi: 10.4314/sajas.v48i2.14

Fray, M.D., Lamming, G.E., Haresign, W. (1995). Induction of ovulation in the acyclic postpartum ewe following continuous, low-dose subcutaneous infusion of GnRH. Theriogenology, 43(6), 1019-1030. Doi: 10.1016/0093-691X(95)00066-H

García, E. (2004). Modificaciones al sistema de clasifiación Climática de Köppen (Quinta edición). Instituto de Geografía-UNAM.

Machmüller, A., Ossowski, D.A., Kreuzer, M. (2000). Comparative evaluation of the effects of coconut oil, oilseeds and crystalline fat on methane release, digestion and energy balance in lambs. Animal Feed Science and Technology, 85(1), 41-60. Doi: 10.1016/S0377-8401(00)00126-7

Mahboub, H.D.H., Ramadan, S.D.H., Helal, M.A.Y., \& Aziz, E.A.K. (2013). Effect of Maternal Feeding in Late Pregnancy on Behaviour and Performance of Egyptian Goat and Sheep and Their Offspring. Global Veterinaria, 11(2), 168-176. Doi: 10.5829/idosi.gv.2013.11.2.74152

Meikle, A., Garófalo, E., Rodríguez-Piñón, M., Tasende, C., Sahlin, L. (2001). Regulation by gonadal steroids of estrogen and progesterone receptors along the reproductive tract in female lambs. Acta Veterinaria Scandinavica, 42(1), 161. Doi: 10.1186/1751-0147-42-161

Morales-Terán, G., Pro-Martínez, A., Figueroa-Sandoval, B., Sánchez-del-Real, C., Gallegos-Sánchez, J. (2004). Amamantamiento continuo o restringido y su relación con la duración del anestro postparto en ovejas Pelibuey. Agrociencia, 38, (2). 165-171.

Morales-Terán, G., Pro-Martínez, A., Salazar-Ortiz, J., Gallegos-Sánchez, J. (2011). Influence of controlled suckling and the male effect on the resumption of postpartum ovarian activity in Pelibuey sheep. Tropical and Subtropical Agroecosystems, 13, (3). 493-500.

NRC. (2007). Nutrient Requirements of Small Ruminants: Sheep, Goats, Cervids, and New World Camelids (p. 11654). National Academies Press. Doi: 10.17226/11654

Palmquist, D. L., Jenkins, T.C. (1980). Fat in Lactation Rations: Review. Journal of Dairy Science, 63(1), 1-14. Doi: 10.3168/jds.S0022-0302(80)82881-5

Pérez-Hernández, P., Hernández-Valdez, V.M., Figueroa-Sandoval, B., Torres-Hernández, G., Díaz-Rivera, P., Gallegos-Sánchez, J. (2009). Efecto del tipo de amamantamiento en la actividad ovárica postparto de ovejas pelibuey y tasas de crecimiento de corderos en los primeros 90 días de edad. Revista Científica de la Facultad de Ciencias Veterinarias, 19(4), 398-402.

Radunz, A.E., Fluharty, F.L., Zerby, H.N., Loerch, S.C. (2011). Winter-feeding systems for gestating sheep I. Effects on pre- and postpartum ewe performance and lamb progeny preweaning performance. Journal of Animal Science, 89(2), 467-477. Doi: 10.2527/jas.2010-3035. 
SAS. (2012). SAS/STAT: User's guide statistics released 9.1. (2nd edition). SAS Institute Inc.

Scaramuzzi, R., Cognié, Y., Downing, J. (1996). The ovarian secretion of androstenedione and oestradiol during late pregnancy and the early postpartum period in sheep with an autotransplanted ovary. Reproduction Nutrition Development, 36(5), 531-543. Doi: 10.1051/rnd:19960509

Shapiro, S.S., Wilk, M.B. (1965). An Analysis of Variance Test for Normality (Complete Samples). Biometrika, 52(3/4), 591-611. Doi: 10.1093/biomet/52.3-4.591

SIAP. (2019). Servicio de Información Agroalimentaria y Pesquera. En: Ovino. Población ganadera 2010-2019. Disponible en: https://infosiap.siap.gob.mx/opt fecha de consulta 20 de septiembre de 2020.

Vicente-Pérez, R., Avendaño-Reyes, L., Álvarez, F., Correa-Calderón, A., Meza-Herrera, C., Mellado, M., Quintero, J., Macías-Cruz, U. (2015). Comportamiento productivo, consumo de nutrientes y productividad al parto de ovejas de pelo suplementadas con energía en el preparto durante verano e invierno. Archivos de Medicina Veterinaria, 47(3), 301-309. Doi: 10.4067/S0301-732X2015000300006 